\title{
VIRAL MARKETING : MEMANFAATKAN KEKUATAN MEDIA SOSIAL DALAM KOMUNIKASI PEMASARAN
}

\section{VIRAL MARKETING : HARNESS THE POWER OF SOCIAL MEDIA IN MARKETING COMMUNICATION}

\author{
Ratna Kartika Sari \\ ratna.rtk@bsi.ac.id \\ Fakultas Komunikasi dan Bahasa, \\ Universitas Bina Sarana Informatika
}

\begin{abstract}
ABSTRAK
Media sosial memiliki peranan besar dalam merubah gaya hidup dan hubungan sosial para penggunanya. Dalam bidang pemasaran, media sosial dimanfaatkan para pemasar bukan hanya untuk berpromosi, namun juga untuk membina hubungan dan menciptakan citra positif melalui kegiatan komunikasi dua arah secara timbal balik, yang akhirnya akan berimbas pada kepercayaan dan peningkatan hasil penjualan produk. Kemudahan, kecepatan, serta daya jangkau media sosial yang sangat luas membuat program pemasaran menjadi efektif dan efisien, kegiatan promosi dapat berlangsung secara cepat dengan biaya yang rendah. Viral marketing yang tercipta memungkinkan isi pesan promosi menyebar secara cepat dan menjangkau banyak pengguna media sosial di berbagai wilayah. Namun, viral marketing juga memiliki berbagai kelemahan yang harus diantisipasi agar tidak menghambat atau menghancurkan program pemasaran yang dilaksanakan. Minat beli konsumen yang didasarkan pada konsep AISAS (Awareness - Interest - Search - Action - Share) harus dipahami oleh setiap pemasar dalam membuat dan menerapkan strategi pemasaran. Dalam penelitian kualitatif ini diuraikan berbagai faktor yang dapat mendukung maupun menghambat kesuksesan viral marketing, serta berbagai fasilitas di media sosial yang dapat dimanfaatkan dalam kegiatan pemasaran. Small and Medium Enterprises (SMEs) dan Sony BMG Music merupakan contoh para pelaku usaha yang merasakan langsung dampak terjadinya viral marketing, baik dampak positif maupun negatif.
\end{abstract}

Kata Kunci: Viral Marketing, Media Sosial, Komunikasi Pemasaran 


\section{ABSTRACT}

Social media have a big role in changing the lifestyle and social relations of its users. In the field of marketing, social media are used by marketers not only to promote, but also to foster relationships and create a positive image through reciprocal two-ways communication, which eventually, will impact on increasing trust and product sales. The ease, speed and reach of social media make marketing programs effective and efficient, promotional activities can spread widely and quickly at a low cost. Viral marketing allows the content of promotional messages to spread rapidly and reach many social media users in various regions. However, viral marketing also has various weaknesses that must be anticipated so as not to inhibit or destroy the marketing program. Consumer purchasing interest based on the concept of AISAS (Awareness - Interest - Search - Action - Share) must be realized by every marketer in creating and implementing marketing strategies.This qualitative research describes viral marketing supporting and inhibiting factors, as well as various facilities in social media that can be utilized in marketing activities. Small and Medium Enterprises (SMEs) and Sony BMG Music are marketers who experienced the impacts of viral marketing, both positive and negative.

Keywords: Viral Marketing, Social Media, Marketing Communication

\section{PENDAHULUAN}

Dunia pemasaran saat ini mengalami perkembangan yang sangat cepat seiring dengan terjadinya perubahan zaman ke arah yang lebih modern. Kondisi masyarakat yang mengarah pada konsep pemasaranpun mengalami perubahan, jika dahulu untuk membeli barang dibutuhkan kesadaran (aware), mencari informasi (attitude), lalu membeli barang tersebut (act), jika puas maka akan membeli lagi (act again), namun saat ini, kegiatan pemasaran lebih mengutamakan pendapat dalam komunitas. Hal itu mengindikasikan bahwa ada faktor lain yang memegang peranan sangat penting dalam kegiatan pemasaran, yaitu faktor komunikasi. Menurut Morrisan, komunikasi merupakan upaya menjadikan seluruh kegiatan pemasaran atau promosi perusahaan dapat menghasilkan citra atau image yang bersifat satu atau konsisten bagi perusahaan (Siswanto, 2013). Senada dengan pendapat tersebut, Etaswara mengungkapkan, bahwa dewasa ini pemasaran telah didudukkan secara strategis dalam proses bisnis dimana komunikasi merupakan determinant factor. Pemasaran di era reformasi ini adalah komunikasi dan komunikasi adalah pemasaran, dimana keduanya tidak pernah bisa dipisahkan. Hal inilah yang membedakan pemasaran modern dengan pemasaran tradisional yang selama ini dijalankan. Pemasaran modern menuntut lebih banyak daripada sekedar mengembangkan produk yang 
bagus, menetapkan harganya secara menarik dan menyediakannya bagi pelanggan sasaran. Perusahaan-perusahaan juga harus berkomunikasi dengan para pelanggan sekarang dan calon pelanggan, dan apa yang perusahaan komunikasikan hendaknya dipersiapkan dengan seksama agar sukses, tidak didasarkan pada pertimbangan untung-untungan (Chrismardani, 2014).

Perpaduan komunikasi dan pemasaran telah berdampak positif bagi kemajuan usaha, sehingga istilah Komunikasi Pemasaran diterapkan oleh banyak pelaku usaha, bahkan menjadi andalan dalam meraih kesuksesan. Komunikasi pemasaran mempunyai peran yang esensial dalam penciptaan ekuitas merek yang positif dan membangun loyalitas merek yang kuat. Melalui usaha komunikasi pemasaran yang efektif dan konsisten, beberapa merek menjadi sangat terkenal sehingga dapat diingat oleh setiap orang dengan tingkat kecerdasan standar. Sebagai contoh, kebanyakan orang yang akrab dengan komputer akan cenderung menyebut Windows jika ditanyakan kepada mereka nama dari paket perangkat lunak yang didesain sebagai sistem operasi (Shimp, 2003).

Penerapan komunikasi pemasaran saat ini banyak memanfaatkan media sosial yang dirasakan sangat memudahkan dan menguntungkan pemasar dalam mempromosikan produknya karena menawarkan konsep "low budget more effect". Kekuatan konsepsi penggunaan media sosial ini memberikan nafas bagi produk lokal maupun internasional untuk mampu menghiasi pasar Indonesia (Iman K, Arifin, \& Mawardi, 2015). Zarella menegaskan, bahwa pada dasarnya media sosial merupakan perkembangan mutakhir dari teknologi-teknologi web baru berbasis internet, yang memudahkan semua orang untuk dapat berkomunikasi, berpartisipasi, saling berbagi dan membentuk sebuah jaringan secara online, sehingga dapat menyebarluaskan konten merek sendiri. Post di blog, tweet, atau video Youtube dapat diproduksi dan dapat dilihat secara langsung oleh jutaan orang secara gratis (Setyani, 2013).

Daya tarik media sosial yang sangat besar memicu para penggunanya untuk lebih kreatif dalam menciptakan dan mengemas isi pesan yang akan disampaikan kepada khalayak. Isi pesan yang menarik akan banyak disukai pembaca, bahkan terbuka kemungkinan untuk disebarluaskan kepada pihak lain dan menjadi viral di dunia maya. Hal seperti ini merupakan peluang bagi pemasar untuk mempromosikan produknya secara cepat dan hemat biaya. Itulah sebabnya viral marketing banyak digunakan dalam kampanye pemasaran di era teknologi modern 


\section{Volume 3 , Nomor 2,}

saat ini. Istilah viral marketing diciptakan oleh Jeffrey F. Rayport dalam artikel yang berjudul The Virus of Marketing. Dalam artikel tersebut tertulis bagaimana jika virus digunakan sebagai sebuah program pemasaran, karena pesan pemasaran akan tersebar dengan hanya menggunakan waktu yang sangat sedikit, anggaran yang tidak perlu terlalu banyak dan dampak yang ditimbulkan sangat luas (Andini, Suharyono, \& Sunarti, 2014). Jadi, 'viral' mengarah kepada kata 'virus' yang menginfeksi lalu menyebar secara cepat dan meluas. Konsep viral marketing juga menggunakan konsep yang sama, yaitu membuat marketing dapat menyebar dalam waktu singkat tanpa usaha promosi dan biaya yang besar.

Cara kerja viral marketing sangat jelas, yaitu memanfaatkan berbagai fasilitas komunikasi yang tersedia di internet. Pride and Ferrell memaparkan, viral marketing is a strategy to get consumers to share a marketer's message, often through e-mail or online video such as YouTube, in a way that spreads dramatically and quickly. Berarti, isi pesan promosi dapat disampaikan melalui pengiriman email ataupun video online yang mampu menarik perhatian khalayak dalam waktu singkat. Selain kedua media tersebut, terdapat media lain yang dapat digunakan dalam penerapan viral marketing, yaitu blog di internet, situs jejaring sosial, dan e-book (Situmorang, 2010). Namun, walaupun mendapat banyak kemudahan dan keuntungan dari penerapan viral marketing tersebut, tetap saja ada kekurangan viral marketing yang harus dipahami dan diantisipasi oleh para pemasar seperti diuraikan Richardson, yaitu sulitnya melakukan kontrol atas persebaran pesan dan ketersampaian isi pesan, hal ini dikarenakan persebaran tidak dapat dikontrol secara pasti (Kurniawan, Novelia, \& Zhukrhufa, 2013).

Berdasarkan uraian mengenai media sosial dan viral marketing di atas, muncul beberapa pertanyaan :

1. Bagaimana media sosial dan viral marketing dapat memberikan kontribusi yang positif bagi dunia pemasaran?

2. Siapa saja pemasar yang secara langsung memiliki pengalaman dengan viral marketing?

3. Hal apa saja yang harus diperhatikan dan diterapkan oleh pemasar dalam penggunaan media sosial dan viral marketing bagi kampanye pemasarannya agar dapat memperoleh hasil yang maksimal.

Penelitian ini bertujuan untuk mengungkap semua permasalahan tersebut dengan mendasarkan semua uraian pada berbagai teori yang terkait. Disamping itu, 


\section{Volume 3 , Nomor 2,}

penelitian ini juga diharapkan dapat memjadi masukan yang berguna bagi para pemasar untuk memperluas wawasan dalam memajukan usaha yang dikelola sesuai dengan tuntutan kemajuan jaman.

\section{METODE PENELITIAN}

Penelitian ini bertujuan memaparkan kekuatan viral marketing dalam menunjang kegiatan pemasaran. Metodologi penelitian yang digunakan adalah kualitatif, yang akan menyelidiki objek yang tidak dapat diukur dengan angkaangka ataupun ukuran lain yang bersifat eksak. Sedangkan data yang digunakan adalah data sekunder, yaitu semua sumber informasi yang berorientasi akademik, yang terkait dengan pokok bahasan penelitian ini baik sumber-sumber informasi berupa media cetak (buku-buku dan jurnal-jurnal ilmiah, tesis) maupun media elektronik (website). Penulis juga memanfaatkan hasil penelitian yang telah dilakukan oleh para peneliti terdahulu yang memiliki relevansi dengan topik permasalahan penelitian ini.

\section{HASIL DAN PEMBAHASAN}

\section{Penelitian yang Relevan}

Manfaat penggunaan viral marketing dalam kampanye pemasaran sangat dirasakan bagi para pemasar di berbagai belahan dunia. Hasic dan Sobtsenko dalam (Barry, Saerang, \& Tumiwa, 2017), menyimpulkan hasil penelitiannya, bahwa viral marketing berpengaruh terhadap kesadaran merek brand awareness dari Small and Medium Enterprises (SMEs), walaupun besaran pengaruhnya berbeda-beda bagi setiap SMEs. Beberapa SMEs mengalami peningkatan brand awereness yang dapat terlihat imbasnya dengan cepat, misalnya terjadi peningkatan penjualan, peningkatan frekuensi kunjungan pengguna ke halaman web, dan peningkatan jumlah pengunjung video kampanye mereka di Youtube. Padahal sebelum penerapan viral marketing yang terjadi hanyalah peningkatan jumlah teman di Facebook dan sedikit peningkatan penjualan. Studi ini menunjukkan bahwa SMEs perlu menerapkan sebanyak mungkin strategi (menggunakan slogan, jingle, simbol). Namun itu belum cukup, mereka juga harus kreatif, unik, dan cerdas saat menerapkan kampanye viral marketing.

Meerman-Scott dalam (Fairbank, 2008) menyarankan agar para pemasar memperhatikan dan mencatat apa yang dikatakan oleh publik dalam berbagai forum 


\section{Volume 3 , Nomor 2,}

dan ruang / papan pesan sehingga berbagai kesan, pesan, dan keluhan para konsumen dapat diketahui dan direspon segera. Sebagai contoh, di tahun 2005 Mark Russinovich menulis dalam blognya atas ketidakpuasannya terhadap beberapa software Sony BMG Music CDs. Hanya dalam beberapa hari saja ratusan komentar merespon pernyataan tersebut sebagai bentuk simpati terhadap Mark serta mengkritik Sony BMG Music. Segera setelah itu, pemberitaan muncul dan meluas hingga akhirnya menjadi berita internasional yang berakibat negatif terhadap merek Sony BMG Music. Hal ini dapat dihindari seandainya Sony BMG Music konsisten memonitor fasilitas online dan segera mengambil langkah-langkah yang tepat untuk menghentikan meluasnya isi pernyataan Mark tersebut.

Berdasarkan hasil penelitian di atas, terlihat bahwa viral marketing dapat menjadi marketing tool yang mendukung pemasaran, namun disisi lain dapat pula berimbas negatif terhadap perusahaan maupun produk-produk yang dihasilkan apabila tidak dimonitor dan dikendalikan secara cepat dan konsisten.

\section{Faktor-faktor Pendukung Viral Marketing}

Viral marketing, yang meramaikan media sosial saat ini, dipercaya memiliki kekuatan besar dalam mencapai tujuan pemasaran. Daya jangkau yang luas dalam waktu singkat, menjadi alasan utama bagi pemasar untuk meraih keuntungan dengan biaya yang rendah. Secara garis besar, keuntungan yang dapat diraih dari terciptanya viral marketing terlihat dalam tabel di bawah ini :

\section{Potential benefits of viral marketing}

\begin{tabular}{|c|c|c|}
\hline Category & Benefit & References \\
\hline \multicolumn{3}{|c|}{ Potential Benefits } \\
\hline Financial & Inexpensive & $\begin{array}{l}\text { (Dobele et al, 2005; } \\
\text { Kaikati \& } \\
\text { Kaikati, 2004, Welker, } \\
\text { 2002) }\end{array}$ \\
\hline \multirow[t]{4}{*}{$\begin{array}{l}\text { Diffusion } \\
\text { speed }\end{array}$} & $\begin{array}{l}\text { Reach audience in a } \\
\text { short time }\end{array}$ & $\begin{array}{c}\text { (Kaikati \& Kaikati, } \\
\text { 2004) }\end{array}$ \\
\hline & Rapid, fast diffusion & $\begin{array}{c}\text { (Helm, 2000; Welker, } \\
\text { 2002) }\end{array}$ \\
\hline & Boost adoption speed & (Dobele et al, 2005) \\
\hline & Exponential & (Helm, 2000) \\
\hline Peer-to-peer & Voluntary transmission & (Dobele et al, 2005) \\
\hline
\end{tabular}




\section{Volume 3 , Nomor 2,}

\begin{tabular}{|c|c|c|} 
transmission & by sender & (Helm, 2000) \\
\cline { 3 - 3 } $\begin{array}{c}\text { Audience } \\
\text { reach }\end{array}$ & $\begin{array}{c}\text { Access to diverse } \\
\text { audience through } \\
\text { social contacts }\end{array}$ & \\
& &
\end{tabular}

Source: Low Jiun Wee Xavier and Goh Yun Shuang Summer (Khaneja, 2016)

Dalam rangka meraih keuntungan dari penerapan viral marketing tersebut, pemasar harus memikirkan dengan cermat isi pesan yang akan disampaikan kepada khalayak, baik isi pesan yang berupa kata-kata maupun gambar / video. Isi pesan yang beredar dapat dimaknai secara positif maupun negatif oleh penerima. Jika isi pesan dimaknai positif, maka akan membawa keuntungan bagi pemasar. Namun, jika isi pesan yang beredar dimaknai negatif, kerugian yang akan dialami, dan sebagai tindaklanjutnya pemasar harus melakukan berbagai upaya untuk memulihkan kepercayaan khalayak. Pengalaman seseorang dalam menggunakan produk tertentu juga dapat menjadi rekomendasi bagi orang lain untuk turut menggunakan atau tidak menggunakan produk tersebut.

Riset yang dilaksanakan White House Department of Consumer Relations mengungkapkan, bahwa $90 \%$ pelanggan yang tidak puas terhadap suatu produk dengan merek tertentu, menyatakan dengan tegas mereka tidak akan lagi membeli produk dari merek tersebut. Setiap pelanggan yang tidak puas berbagi pengalaman buruknya kepada 9 orang dan 13\% lainnya berbagi kepada lebih dari 20 orang. Sedangkan pelanggan yang puas dengan produk yang dibeli, berbagi pengalaman kepada lebih dari 5 orang. World of mouth pengalaman negatif menggunakan produk itu ternyata berdampak sangat besar, $74 \%$ khalayak yang mendengar atau membacanya lebih memilih membeli produk sejenis dari merek lain yang berbeda (Akyol, 2013).

Seorang pemasar yang menyadari kekuatan viral marketing pasti akan memanfaatkan, bahkan memaksimalkan penggunaan media sosial dalam penyampaian isi pesan promosinya. Penyusunan dan penyampaian isi pesan promosi tersebut harus berorientasi pada faktor-faktor pendukung viral marketing itu sendiri, yang meliputi :

1) Konsumen

Konsumen saling terhubung dengan lainnya dalam hubungan interpersonal. Anggota keluarga dan kerabat saling berinteraksi secara teratur. Ada dua komponen yang membentuk interaksi antar konsumen yaitu frekuensi dan interaksi. Frekuensi 


\section{Volume 3 , Nomor 2,}

adalah seberapa sering interaksi terjadi diantara konsumen. Sedangkan kekuatan menunjukan level keterikatan dalam interaksi tersebut. Level keterikatan ini bisa terlihat dari keakraban, keintiman, kebersamaan dan sebagainya. Makin akrab pembicaraan antar konsumen, makin erat hubungan di antara mereka. Melalui interaksi tersebut infomasi mengenai produk, layanan, dan bisnis mengalir dalam suatu jaringan konsumen. Akhirnya, terjadilah pemasaran dari mulut ke mulut.

\section{2) Buzz}

Keberhasilan viral marketing tidak hanya bergantung pada konsumen, untuk dapat berhasil diperlukan topik yang hangat, menarik, dan unik untuk dibicarakan dengan konsumen lain. Tanpa topik yang menarik, pemasaran tidak akan menyebar dengan sendirinya. Topik yang menarik seperti gosip, berita terkini terbukti membuat orang ramai membicarakannya dengan sukarela. Topik pembicaraan ini disebut dengan istilah buzz.

3) Kondisi yg mendukung

Ada dua faktor psikologi pendukung yang membuat konsumen terdorong untuk membicarakan suatu produk secara positif :

a. Peer Pressure

Peer pressure adalah pengaruh dari kelompok sebaya, sejenis (peer group) agar seseorang mengubah prilaku, kebiasaan dan nilai dirinya sehingga dapat diterima dalam kelompok tersebut. Peer pressure memberikan tekanan pada seseorang untuk mengikuti kelompoknya, baik dia sebenarnya menginginkannya atau tidak. Peer pressure membuat orang melakukan sesuatu yang biasanya tidak ia lakukan.

b. Prestise

Prestise atau kebanggaan pada dasarnya merupakan kebutuhan semua orang. Semua orang ingin dipandang dan dihormati oleh orang sekitarnya.

Orang melakukan berbagai cara untuk membuat dirinya lebih terpandang, mulai dari membeli barang-barang mewah, tampil dimuka umum, berderma dan salah satunya dengan menunjukan pengetahuan dan kepandaian yang dimilikinya. Salah satu bentuk dari kegiatan itu adalah menceritakan kepada orang lain mengenai produk yang dikenalnya. Seseorang yang menceritakan sebuah produk berteknologi seperti komputer kepada orang lain, merasa bangga jika produk yang diceritakan dan direkomendasikan tersebut kemudian dipakai oleh orang lain (Wahyuni, 2016). 


\section{Volume 3 , Nomor 2,}

Uraian di atas mengisyaratkan, bahwa pemasar tidak hanya dituntut untuk membuat dan mengemas isi pesan secara menarik, namun juga memperhatikan pengalaman dan kondisi psikologis konsumen. Daya tarik isi pesan yang tinggi tidak akan berarti apabila konsumen tidak memperoleh kepuasan berkaitan dengan kualitas produk dan pelayanan yang diberikan, sehingga viral yang tercipta tidak memberi manfaat seperti yang diharapkan.

Oleh sebab itu, pemasar harus mampu menerapkan strategi yang tepat dalam program pemasarannya agar viral yang tercipta mengarah pada pencapaian tujuan pemasaran yang telah ditetapkan. Strategi viral marketing diklasifikasikan dalam dua kategori berdasarkan tingkat keterlibatan customers dalam pemasaran seperti diuraikan Skrob dalam (Wardhana \& Pradana, 2016) : low integration strategy and high integration strategy. In low integration strategy, customers' involvement was minimal where the spread of promotions by email only with recommendation "send to friend". In the other hand, in high integration strategy, customers' level of involvement is active in capturing new customers.

Jadi, tingkat keterlibatan konsumen dalam viral marketing dapat saja rendah (minimal), namun dapat pula tinggi (mampu menarik konsumen baru). Untuk meraih tingkat keterlibatan tinggi dari konsumen, pemasar harus terlebih dahulu memiliki pemahaman yang luas mengenai minat beli konsumen terhadap suatu produk. Hal ini terkait dengan konsep yang diperkenalkan oleh Dentsu, yaitu konsep AISAS (Awareness - interest - Search - Action-Share) yang muncul pada era digital saat ini. Konsep ini merupakan pengembangan dari konsep AIDA (Awareness - Interest - Desire - Action) yang dipopulerkan pada tahun 1989. Secara detail, penjelasan konsep AISAS sebagai berikut :

- Awareness

Dalam suatu promosi, Source/Brand berusaha menarik perhatian lewat berbagai cara promosi untuk menarik audiens.

- Interest

Audiens yang sudah tertarik perhatiannya dengan apa yang ditawarkan oleh Source/Brand, ada rasa ketertarikan lebih dalam untuk mengetahui apa yang ditawarkan.

- Search

Pencarian menjadi step berikutnya menggantikan Desire atau keinginan. Karena kemajuan teknologi ini, seseorang yang berkeinginan dapat mencari apa yang 


\section{Volume 3 , Nomor 2,}

Desember 2019

\section{CERMIN : JURNAL PENELITIAN}

diinginkan melalui media internet. Search menjadi sangat krusial. Semakin mudah dicari, maka audiens semakin tertarik. Dalam hal ini, penggunaan search engine atau mesin pencari di internet seperti google dan yahoo sangat mendukung pencarian untuk pengambilan keputusan.

- Action

Promosi dikatakan berhasil apabila konsumen sudah melakukan purchasing atau pembelian suatu produk/jasa. Dalam hal konten, audiens yang membuka link, atau minimal pergi ke salah satu situs web tempat konten itu berada. Hal ini merupakan interaksi yang krusial dan menentukan ke tahap selanjutnya.

- Share

Pada era digital ini, audiens merasa bahwa hal yang ia dapatkan, entah itu produk atau jasa dapat memberikan feedback dan komunikasi dua arah secara cepat. Hal ini juga dipengaruhi oleh Buzzer, dan audiens yang mengulas produk, yang biasa ditemukan oleh audiens lain yang mencari hal yang mereka inginkan. Konsep AISAS ini memungkinkan seseorang melakukan pencarian feedback mengenai produk yang diberikan oleh audiens lain, dapat mempengaruhi pilihan audiens (Sebastian, 2015).

\section{Aplikasi Viral Marketing}

Penyampaian isi pesan promosi yang diharapkan akan berkembang menjadi viral dapat dilakukan dengan memanfaatkan kecanggihan teknologi yang menyediakan berbagai fasilitas, antara lain :

1). E-mail

E-mail sudah sejak lama digunakan sebagai media untuk menyampaikan pesan. Meskipun sekarang ini e-mail sudah kalah populer dibandingkan situs jejaring sosial tetapi masih banyak orang ataupun perusahaan yang menggunakan e-mail sebagai media untuk mengirim pesan berupa penawaran dan promosi. E-mail akan selalu dibutuhkan karena untuk menjadi anggota situs jejaring sosial juga harus menggunakan sebuah alamat $e$-mail.

2). $B \log$

Blog pernah menjadi tren tersendiri di dunia teknologi informasi. Blog menjadi sangat populer karena pembuatan sebuah blog tidak sesulit dibandingkan membuat sebuah web. Membuat web membutuhkan ketrampilan khusus yang tidak semua orang mudah melakukannya sementara membuat blog dianggap lebih mudah 


\section{Volume 3 , Nomor 2,}

karena merupakan model aplikasi saja pada sebuah situs. Sebagaimana e-mail maka sebuah blog tidak hanya untuk tujuan sosial, namun dapat dimanfaatkan sebagai sebuah media promosi dalam bisnis.

3). Situs jejaring sosial.

Keberadaan situs-situs jejaring sosial merupakan fenomena tersendiri saat ini. Situs jejaring sosial yang populer ada beberapa antara lain MySpace, Friendster, Facebook dan Twitter. Pada dasarnya, sebuah situs jejaring sosial adalah sebagai sarana sosial untuk berkomunikasi di internet dengan cepat, mudah dan massal. Namun, pengguna situs jejaring sosial yang sangat banyak dilihat oleh para pemasar sebagai peluang untuk menawarkan ataupun mengiklankan sesuatu apapun yang bisa dijual.

Jadi disini dapat dikatakan bahwa pengguna situs yang banyak itulah yang mempengaruhi para pemasar untuk melakukan aktivitas pemasaran di internet lewat sebuah situs jejaring sosial. Pemasaran viral diharapkan dapat segera terjadi karena banyak pengguna Facebook misalnya, yang sangat aktif sepanjang hari sehingga dapat sebagai pembawa atau pengirim pesan kepada temannya secara cepat.

\section{4). Video viral}

Video viral merupakan bentuk pemasaran viral yang makin populer belakangan ini. Video viral adalah sebuah video yang menjadi populer melalui proses berbagi di internet dan secara khusus biasanya melalui media situs berbagi video. Dalam persaingan bisnis biasanya ada satu yang menonjol dan dalam persaingan situs berbagi video yang paling populer adalah YouTube. Situs ini semakin terkenal karena sering menampilkan gambar-gambar video yang mengundang kontroversi. Video-video yang dikirim ke situs berbagi video dengan cepat sangat populer di seluruh dunia apabila video itu mampu mencuri perhatian beberapa orang yang melihatnya dan kemudian orang itu menyampaikan pesan kepada temannya bahwa ada gambar atau klip video yang (sangat) menarik di salah satu situs berbagi video, anggap saja situs YouTube yang sangat populer. Penyebaran pesan bahkan video itu sendiri kepada orang lain sangat sesuai dengan cara-cara pemasaran viral.

\section{5). E-book viral}

E-book adalah tampilan digital sebuah buku atau bacaan yang disajikan lewat internet. Perpustakaan-perpustakaan di seluruh dunia sudah banyak yang menyediakan fasilitas e-book. Tujuannya agar para pembaca dapat mengakses e-book tersebut tanpa harus perlu datang ke perpustakaan. Model lain sejenis 


\section{Volume 3 , Nomor 2,}

e-book adalah e-journal. Bagi sebagian besar pemilik bisnis online, e-book viral kemungkinan adalah bentuk pemasaran viral yang paling mudah dan paling efektif. Pemasaran viral adalah cara yang sangat baik untuk mendapatkan penerima $e$-book mempromosikan kita sebagai pemilik e-book kepada langganan mereka, teman dan siapapun yang membutuhkan. Penerima yang berikut selanjutnya akan mempromosikan e-book tersebut kepada pihak lain dan demikian seterusnya. Hal tersebut merupakan sebuah metode yang sangat efektif dalam pemasaran (Situmorang, 2010).

Semua media penyampaian pesan promosi di atas akan memberikan banyak manfaat apabila pemasar memiliki kemampuan dan pengetahuan yang baik dalam pengelolaannya. Berbagai masalah dapat muncul saat isi pesan yang disampaikan menjadi viral, misalnya:

1. Brand Control : the problem with viral marketing is that you have no control over your branding. You don't know ahead of time whom an individual is going to contact. As a result, many of your messages may end up with people outside the target audience. Moreover, in some cases, individuals may modify the message or add something to it. This leads to variability in how your brand is perceived, something you don't want.

2. Uncharted Growth : Viral Marketing can lead to unanticipated growth paths. For example, Hotmail is now one of the leading email providers in India. It is not clear if it expected that or even wanted that. However, many individuals started emailing friends in India who emailed many more. Such growth paths may lead to abrupt changes in strategic direction, which can be problematic.

3. Lack of Measurement : You can't always track who received the emails and what they did with them. In many cases, it may not be possible to tell if people who adopted your service did so because of your viral marketing technique or otherwise. So it's difficult to track and measure. Compare this with techniques such as banner advertising, where measurement is now an advanced science.

4. Spam Threats : Finally, if done poorly, viral marketing can lead to large-scale spam issues. Consider a company that pays individuals to email their friends to convince them to buy one of its products. In this case, the individual who receives the email had only given the friend permission to send email of a personal nature. The one friend's receiving an unsolicited commercial email can weaken his or her relationship with the person who sent it. This can lead to the recipient of the email 


\section{Volume 3 , Nomor 2,}

dropping a friend and becoming angry with the marketer for sending an unsolicited message. Flames may result, leading to damage to the advertiser's reputation. In some cases, individuals who want to earn more money simply go out and spam people. This can be problematic for your company image.

(Deepa \& Thenmozhi).

Dengan mamahami masalah-masalah yang berpotensi muncul, pemasar diharapkan akan lebih cermat dalam pemilihan media, yang tentu saja harus disesuaikan dengan isi pesan yang akan disampaikan, kemudian melakukan pemantauan terus menerus setelah isi pesan diluncurkan, serta menyiapkan berbagai alternatif solusi penyelesaian masalah tersebut.

Semua pemasar mengharapkan dapat meraih kesuksesan dalam penerapan viral marketing. Ferguson menyebutkan ada empat hal penting yang harus dilakukan dalam rangka meraih kesuksesan penerapan viral marketing tersebut, yaitu :

- The use of tactics in building consumer awareness and desire to try (use tactics to build awareness and trial)

- Identification of the company's products are offered at each time the consumer visits to a specific page

(no acquisition without identification)

- Build behavioral recommend for consumers to conduct transactions (look beyond the transactional)

- Build awareness to continue to develop products according to customer needs (connect your advocates to product development).

(Wardhana \& Pradana, 2016).

Intinya, kesuksesan penerapan viral marketing ditentukan oleh terbangunnya kesadaran dan keinginan konsumen untuk mencoba produk yang ditawarkan, penyediaan informasi mengenai produk yang dapat diakses setiap saat oleh konsumen, kemampuan membangkitkan minat konsumen untuk melakukan transaksi, dan kemampuan membangkitkan kesadaran untuk terus memperbaiki dan mengembangkan produk sesuai dengan kebutuhan konsumen.

Semua hal terkait dengan viral marketing seperti telah diuraikan dalam penelitian ini, hendaknya diperhatikan, dipahami, dan diterapkan oleh semua pemasar agar kampanye pemasaran yang dilaksanakan dapat berlangsung secara lancar dan menghasilkan hal positif sesuai yang diharapkan. Pengalaman negatif 


\section{Volume 3 , Nomor 2,}

yang dialami Sony BMG Music seperti diulas dalam Penelitian yang Relevan di bab sebelumnya, menjadi pelajaran yang berharga bagi para pemasar agar lebih aktif memantau isi pesan yang beredar di media massa dan melakukan berbagai upaya untuk mencegah respon negatif meluas ke pengguna media massa yang lain.

\section{PENUTUP}

Perubahan era yang terjadi begitu cepat dari era konvensional ke era modern yang ditandai dengan kehadiran teknologi internet, khususnya media sosial, telah merubah perilaku masyarakat penggunanya, baik dalam kehidupan pribadi maupun dalam interaksi sosial. Penerapan strategi pemasaran melalui media sosial yang berbasis jejaring sosial dan website hingga saat ini merupakan pilihan yang dianggap paling tepat jika dibandingkan dengan pemasaran melalui cara konvensional. Dalam dunia bisnis, hal ini merupakan tantangan sekaligus peluang besar bagi para pemasar untuk lebih mendekatkan diri kepada konsumen dan memperluas jangkauan pemasarannya dalam waktu singkat dengan biaya yang lebih murah. Penggunaan media sosial dalam kegiatan pemasaran memungkinkan terjadinya interaksi yang cepat dan langsung megarah pada khalayak. Namun, kemudahan mengakses dan menggunakan media sosial harus diimbangi dengan kemampuan pemasar dalam menyikapi berbagai masalah atau kendala sebagai wujud dari kelemahan media sosial itu sendiri.

Penerapan viral marketing harus dimasukkan sebagai bagian dari rencana strategis kampanye pemasaran, sehingga perlu perencanaan yang matang, dilengkapi dengan langkah-langkah antisipasi yang dapat segera dilaksanakan apabila hal yang tidak diinginkan terjadi. Keaktifan memantau peredaran isi pesan di media sosial menjadi kewajiban setiap pemasar dalam upaya mencegah semakin meluasnya isi pesan yang bersifat negatif dan dapat merusak reputasi pemasar maupun produk-produk yang dipasarkan. Konsep AISAS (Awareness - interest Search - Action- Share) yang mendasari minat beli konsumen sangat tepat diterapkan di era teknologi modern saat ini dimana semua konsumen dapat mencari dan berbagi informasi mengenai produk yang dibelinya kepada orang lain. Hal ini harus menjadi pemicu bagi pemasar untuk meningkatkan kualitas produk maupun pelayanan kepada konsumen, serta lebih berhati-hati dalam menerapkan viral marketing. 


\section{DAFTAR PUSTAKA}

Akyol, S. (2013). Social Media and Marketing : Viral Marketing. Academic Journal of Interdisciplinary Studies .

Andini, N. P., Suharyono, \& Sunarti. (2014). Pengaruh Viral Marketing Terhadap Kepercayaan Pelanggan dan Keputusan Pembelian (Studi Pada Mahasiswa Fakultas Ilmu Administras Universitas Brawijaya Angkatan 2013 Yang Melakukan Pembelian Online Melalui Media Sosial Instagram). Jurnal Administrasi Bisnis (JAB) , II, 2.

Barry, H. G., Saerang, D. P., \& Tumiwa, J. R. (2017). Dampak Pemasaran Viral Menggunakan Platform Media Sosial Terhadap Kesadaran Merek (Studi Kasus : Kosmetik Laneige). Jurnal EMBA , 5, 3947.

Chrismardani, Y. (2014). Komunikasi Pemasaran Terpadu : Implementasi Untuk UKM. Jurnal NeO-Bis , 8, Nomor 2, 180.

Deepa, N., \& Thenmozhi, S. (n.d.). Viral Marketing As An On-Line Marketing Medium. IOSR Journal of Business and Management (IOSR-JBM) , 92.

Fairbank, V. (2008). A Study Into The Effectiveness of Viral Marketing Over The Internet.

Iman K, D., Arifin, Z., \& Mawardi, M. K. (2015). Pengaruh Pemasaran Melalui Media Sosial Terhadap Kesadaran Konsumen Pada Produk Internasional, Studi Pada Pengguna Produk Uniqlo Di Indonesia. Jurnal Administrasi Bisnis , vol.24, 3.

Khaneja, S. (2016). Viral Marketing: A Magic Wand To Success. International Journal of Management Research , 4 (7), 98.

Kurniawan, B., Novelia, \& Zhukrhufa, S. (2013). Membangun Pemasaran Viral : Studi Kasus Twitter@Soyjoy ID. 9.

Sebastian, G. (2015). Analisis Viral Marketing Youtube : Studi Terhadap Tayangan "Kenapa Rupiah Melemah?" Dari Saluran Kok Bisa. 14.

Setyani, N. I. (2013). Penggunaan Media Sosial Sebagai Sarana Komunikasi Bagi Komunitas; Studi Deskriptif Kualitatif Penggunaan Media Sosial Twitter, Facebook dan Blog Sebagai Sarana Komunikasi Bagi Komunitas Akademi Berbagi Surakarta. 6.

Shimp, T. A. (2003). Periklanan dan Promosi dan Aspek Tambahan Komunikasi Pemasaran Terpadu (alih bahasa) (edisi kelima ed.). Jakarta: Penerbit Erlangga.

Siswanto, T. (2013). Optimalisasi Sosial Media Sebagai Media Pemasaran Usaha Kecil Menengah. Jurnal Liquidity , 2, 81.

Situmorang, J. R. (2010). Pemasaran Vira 1 - Viral Marketing. Jurnal Administrasi Bisnis , 6,62 . 
Wahyuni, I. (2016). Strategi Viral Marketing Melalui Instagram Dalam Meningkatkan Penjualan (Studi Deskriptif Kualitatif Pada Selfie Contest Avoskin Beauty. 24.

Wardhana, A., \& Pradana, M. (2016). Viral Marketing Determinants of Top Online Shop Brands In Indonesia. Jurnal MIMBAR, vol. 32, 25. 